This item was submitted to Loughborough's Research Repository by the author.

Items in Figshare are protected by copyright, with all rights reserved, unless otherwise indicated.

\title{
Local peacebuilding in a victor's peace. Why local peace fails without national reconciliation
}

PLEASE CITE THE PUBLISHED VERSION

https://doi.org/10.1080/13533312.2019.1583559

PUBLISHER

(C) Taylor \& Francis (Routledge)

\section{VERSION}

AM (Accepted Manuscript)

\section{PUBLISHER STATEMENT}

This is an Accepted Manuscript of an article published by Taylor \& Francis in International Peacekeeping on 01 Mar 2019, available online: https://doi.org/10.1080/13533312.2019.1583559

\section{LICENCE}

CC BY-NC-ND 4.0

\section{REPOSITORY RECORD}

Piccolino, Giulia. 2019. "Local Peacebuilding in a Victor's Peace. Why Local Peace Fails Without National Reconciliation”. figshare. https://hdl.handle.net/2134/36965. 


\title{
Local peacebuilding in a victor's peace. Why local peace fails without national reconciliation
}

This is an Accepted Manuscript version of an article that will be published by Taylor \& Francis in International Peacekeeping, DOI: 10.1080/13533312.2019.1583559

\section{Giulia Piccolino ${ }^{\mathrm{a}}$}

${ }^{a}$ Politics and International Studies, Loughborough University, Loughborough, LE113TU, United Kingdom.

Office telephone: $+44(0) 1509223656$

Email: g.piccolino@lboro.ac.uk

ORCID: https://orcid.org/0000-0002-6817-6542

\begin{abstract}
The literature on peacebuilding has increasingly emphasized the importance of the local level - a trend that has been called the local turn. For some researchers, the local turn can improve international peacebuilding interventions, while for others it is an agenda to promote an emancipatory and legitimate peace. There is however mixed evidence backing the argument that addressing local level issues in peacebuilding can make a substantial difference. The local turn reposes on assumptions that appear particularly problematic in an environment characterised by the lack of an elite-level pact, such as a conflict terminated in a military victory. Looking at the crisis in Côte d'Ivoire, which terminated in 2011 with the defeat of former president Laurent Gbagbo, this paper highlights how the lack of elite level reconciliation compromises the effectiveness of actions aiming to promote local 'social cohesion'. It also shows how the discourse and practices of the local turn can be appropriated by semi-authoritarian post-conflict governments in order to depoliticize the peacebuilding process. It concludes that the popularity of the 'local turn' among peacebuilders might be due more to the
\end{abstract}


opportunity that it offers to eschew delicate national-level political issues, than to its supposed emancipatory potential.

Keywords: peacebuilding; local turn; victory; Africa; Côte d'Ivoire

\section{Acknowledgements}

Fieldwork on which this work is based was supported by the Alexander Von Humboldt Foundation, through an Alexander Von Humboldt post-doctoral fellowship. I would like to thank John Heathershaw, Maria Martin de Almagro, the editor Philip Cunliffe and the anonymous reviewers for useful comments that have helped me to improve the manuscript. I would also thank Kai Kenkel for the opportunity to present an earlier version of this article at a workshop at the Pontifical Catholic University of Rio de Janeiro.

\section{Disclosure statement}

No potential conflict of interest was reported by the author. 


\section{Introduction}

The literature on peacebuilding has increasingly emphasized the importance of the local level - a trend that has been called the local turn. For some researchers, more attention paid to the local level can improve international peacebuilding interventions. More ambitiously, for other scholars the local turn is an agenda to promote an emancipatory and legitimate peace. However, the local turn agenda has also been criticized for its theoretical and conceptual vagueness, and for the exaggerate expectations that it places in the potentialities of the local.

Programmes aiming at fostering dialogue and reconciliation between local communities are now implemented in most post-conflict countries, irrespectively from how the conflict terminated. However, the local turn reposes on some assumptions that appear particularly problematic in a political environment characterised by the lack of elite-level reconciliation, as in the case of countries where peace was achieved through military victory. Moreover, the literature on the local turn often neglects the role of the state and the connections between 'local' citizens and the political elite, which are strengthened in many post-conflict settings by the neo-patrimonial nature of local politics.

This article problematizes the local turn by unpacking the mechanisms that link local and national level peace in a 'victor's peace' context. The first two sections look at the literature on the local turn and question its assumptions. I then present in the third section my theoretical framework, which I apply in the following sections to the case of Côte d'Ivoire, whose politico-military crisis terminated in 2011 with the defeat of former president Laurent Gbagbo and his allies.

Côte d'Ivoire is a country where the argument of the local turn seems to make sense at first. Community conflicts around land tenure played an important role in the outbreak of the 
conflict and violence against civilians followed localized patterns. ${ }^{1}$ The country is also a good case to investigate the consequences of a 'victor's peace', having experienced both a post-negotiation and a post-victory war-to-peace transition. ${ }^{2}$

The article shows how the discourse and practices of the local turn, first promoted in Côte d'Ivoire by the international community under the label of 'social cohesion', were appropriated by the Ivorian government after 2011. However, many Ivorians, especially those who have supported the losing side during the Ivorian crisis, rejected the idea that community reconciliation is the key to peace and emphasized the importance of addressing national level issues in order to achieve a legitimate peace.

\section{The local turn}

The debate on peacebuilding in recent years has been marked by a renewed attention at the local level. This development, labelled the local turn, has been stimulated by the convergence of the agendas of two groups of actors, one motivated by the desire to improve the peacebuilding interventions of international institutions and the other by the normative reflection about how to arrive to a more just and legitimate peace. In this section, I summarize the arguments of both groups and I subsequently discuss the criticism that has been advanced against the idea that the 'local' is key to peace and to the policy practices that the local turn has inspired.

On the one hand, on the 'problem-solving' side, scholars and practitioners have reflected on the reasons why certain international interventions have failed in spite of the

\footnotetext{
1. Allouche and Jackson, "Zones of peace".

2. Piccolino, "Peacebuilding and statebuilding in post-2011 Côte d'Ivoire".
} 
substantial investments made by the international community. In this context, several analysts have pointed out to the need to address sub-national level conflict and governance issues and to involve local communities in peacebuilding. This trend has been encouraged by the evolution of recent scholarship on civil wars, which has increasingly adopted a sub-national research design and showed that in many countries labelled as 'at war', violence is not distributed uniformly across national territory. ${ }^{3}$

Séverine Autesserre's book on the crisis in the DRC has been particularly influential in pointing out to the importance of local peacebuilding. ${ }^{4}$ The study, widely read and discussed in the practitioners' community, argues that the international peacebuilding intervention in the DRC failed because practitioners were focused on the success of the national level peace process and of the 2006 elections. Confident that peace would have 'trickled down', they ignored the local conflicts over land and citizenship that were fuelling extreme violence in the Eastern Congo. Such violence, however, has endured in spite of the apparent progress of the nation-level peace process and the installation of an elected president in Kinshasa.

While scholars like Autesserre do not question the legitimacy of intervention, but aims to improve it, other scholars have promoted the local turn as part of a more radical contestation of international peacebuilding interventions. Building on the classic work of scholar-activists, such as John Paul Lederach, ${ }^{5}$ these authors have presented the local turn as a way to develop an alternative approach to peacebuilding. ${ }^{6}$ Liberal peacebuilding has been presented as a hegemonic discourse that marginalizes local knowledge and needs, creating a

3. Kalyvas, The Logic of Violence in Civil War; Allouche and Jackson, "Zones of peace".

4. Autesserre, The Trouble with the Congo.

5. Lederach, Building Peace.

6. Mac Ginty and Richmond, "The Local Turn in Peace Building." 
'virtual peace'. ${ }^{7}$ These scholars have presented as an alternative an emancipatory peace built from below, through local initiatives and everyday interactions that are legitimate and have a concrete impact on the life of citizens and communities. ${ }^{8}$

The local turn has today entered in the mainstream discourse of international agencies and NGOs. ${ }^{9}$ The view that it is important to broaden conflict resolution and peacebuilding beyond an elite pact, taking into consideration the local dimension and the preoccupations of the population at large has become generally accepted. The vagueness and compatibility with different theoretical and normative approaches to peacebuilding of the 'local turn' has helped its success. However, the theory and practice of the local turn have also been criticized.

A first set of criticism of the local turn focuses on the problem-solving arguments used to promote it. The early literature on local peacebuilding did not deny the importance of national level peacemaking but argued that it was necessary to promote peace at multiple levels. In Lederach's Conflict Transformation theory, for instance, grassroots peacebuilding was seen as part of a 'multi-track' agenda, where it complemented 'track 1' (national level peace process) and 'track 2' (dialogue at the level of middle-range elites, such as intellectuals and civil society activists) peacemaking processes. ${ }^{10}$ Some of the recent academic and policy discourse, however, has tended to represent 'top down' and 'bottom up' strategies as alternative options and to dismiss or downplay efforts to push for change at the national level, particularly democratic change, as a faulty 'top down' strategy. For instance, in a series of op eds published in 2018 and 2019, Autesserre restated her view that peacebuilding at the local

7. Richmond, A Post-Liberal Peace, p. 95.

8. Mac Ginty and Richmond, "The Local Turn in Peace Building."

9. Mac Ginty, "Where Is the Local?"

10. Lederach, Building Peace. 
level is the true key to tackle conflicts and accused international peacebuilders to pay too much attention to elections and democratization. ${ }^{11}$

However, Autesserre and other advocates of local peacebuilding have been accused to replace the expectation of a 'trickle down' effect with an opposite but equivalent expectation that local initiatives might automatically trigger national level peace. ${ }^{12}$ Empirical research casts doubt on the assumption that addressing local issues is always key to achieve lasting peace. A recent study systematically compared the local dimension of power-sharing agreements in six sub-national regions belonging to three African countries. ${ }^{13}$ In two of the countries studied - Liberia and Burundi - peace agreements neglected local contentious issues, but a series of favourable factors resulted in the effective reestablishment of peace at the local level. By contrast, in contradiction with Autesserre's analysis, the authors find that peace agreements in the DRC have indeed incorporated several key local issues, but this has not been sufficient to bring peace back to conflict-affected areas. This observation is comforted by further research on the DRC, which has showed that the armed groups protagonist for much of the violence in the East after the 2006 elections did not mobilize spontaneously around local issues, but had strong ties with national level elites in the DRC and in neighbouring Rwanda. ${ }^{14}$

The normative argument in favour of the local turn advanced by the critical peacebuilding literature has also several problematic aspects. ${ }^{15}$ First, as the scholars who

11. Autesserre, "There's another way to build peace". See also Autesserre, "The Crisis of Peacekeeping".

12. Ernstorfer, Chigas, and Vaughan-Lee, "From Little to Large."

13. Simons, Zanker, Mehler and Tull, "Power-Sharing in Africa's War Zones."

14. Stearns, "The Trouble with the Congo."

15. Mac Ginty, "Where Is the Local?" 
promote bottom-up peacebuilding themselves recognize, the local turn agenda is vulnerable to being co-opted by international actors and, in the process, voided from its more radical implication. ${ }^{16}$

A second risk is less frequently remarked: the co-optation of the local turn agenda not by the international community, but by the national government and the political elite. The national level is singularly absent from the analysis of critical scholars, which tends to represent post-conflict spaces as marked by a tension between the liberal peace promoted by international policy makers and a local dimension identified with customary practices and identity politics. ${ }^{17}$ The national government and state apparatus is either conflated with the 'international' - when the country is under international administration - or with the 'local' when state elites' clientelist practices clash with liberal peacebuilding prescriptions. Yet, a number of cases show that state elites in post-conflict countries play an autonomous and often central role with respect to both international peacebuilders and local communities. ${ }^{18}$ These elites often aspire to implement some form of illiberal modernisation and prioritize stability and economic growth over democratization and human rights. ${ }^{19}$

At first sight, the approach of illiberal elites is at odds with the local turn - they are engaging in top-down projects where the concerns of local level communities are often marginalized or ignored. However, on another level, these elites appreciate the de-emphasis of the typical components of liberal peacebuilding - elections, democratization, equitable transitional justice - by some of the proponents of the local turn. National elites that are in

\footnotetext{
16. Mac Ginty, "Where Is the Local?"

17. Richmond, A Post-Liberal Peace.

18. Heathershaw, Post-Conflict Tajikistan.

19. Jones, Soares de Oliveira, and Verhoeven, Africa's Illiberal State-Builders; Lyons, "Victorious Rebels and Postwar Politics".
} 
charge of post-conflict states have often an interest in downplaying the national political roots of some local cleavages. ${ }^{20}$ It is advantageous to them to present 'conflict' and 'peace' as matters of interpersonal harmony and everyday interaction, decoupling them from the national level political sphere. Similarly, they might benefit from confining international peacebuilders to implement small local level interventions, while they remain in control of key national level processes of statebuilding, electoral politics and transitional justice. Empirical case studies from countries otherwise as different as Rwanda ${ }^{21}$ and Tajikistan ${ }^{22}$ have showed how authoritarian regimes use discourses of 'grassroots peacebuilding' and 'local ownership' to foster illiberal projects and reinforce their grasp on civil society.

In the next paragraph, I explore the problem of the linkage between national and local level peace and its consequences for countries that have experienced a conflict terminated with a military victory. My theoretical discussion focuses in particular on societies where the dominant way in which politics works is neo-patrimonial, based on patron-client ties between politicians and local communities. Both the mode of conflict termination and the characters of politics in these countries complicates the idea of an autonomous local level.

\section{Peace and conflict at the national and local level}

The research on the role played by local level conflicts published after 2000 is to a large extent a reaction to the previous literature on ethnic conflicts and genocide, which was overemphasizing the role played by elite instrumentalization and top-down propaganda in mass

20. Lewis, Heathershaw, and Megoran, "Illiberal Peace?"

21. Piccolino, "Winning Wars, Building (Illiberal) Peace?".

22. Heathershaw, Post-Conflict Tajikistan. 
violence. This literature had difficulties in explaining 'how elites can convince their followers to adopt false beliefs and take actions that the followers would not want to take if they understood what the leaders were up to'. ${ }^{23}$ More recent work, however, has been able to give some answers to this puzzle. I consider here in particular the literature on the micro-dynamics of conflicts ${ }^{24}$ and the research on 'horizontal inequalities'. ${ }^{25}$

The literature on the micro-dynamics of conflicts suggests that in some cases local actors do not need to adopt their leaders' 'false beliefs' in order to take action: they might be following their own agenda and be driven by personal concerns, such as preoccupations for their own security, a quest for material advantages or the desire to settle private feuds. In other words, there is 'considerable local input and initiative in the production of violence'. ${ }^{26}$ Because Stathis Kalyvas notices the disjunction between national and local level conflicts, his work has been used to justify the importance of local peacebuilding. ${ }^{27}$ However, a closer look at Kalyvas's analysis does not warrant this interpretation. Kalyvas portrays the escalation of micro-level conflicts to physical violence as a consequence of the dynamics of the national level conflict and of the battle for territorial control that the government and the insurgents are waging. ${ }^{28}$ Once war has broken out, civilians are forced to take side. In many cases, they do it in order to protect themselves, because belligerents in an irregular war use selective violence to force civilians to collaborate, but they can also have private and personal interests

23. Fearon and Laitin, "Violence and the Social Construction of Ethnic Identity", p. 853.

24. Kalyvas, The Logic of Violence in Civil War.

25. Stewart, Horizontal Inequalities and Conflict; Cederman, Weidmann, and Gleditsch, "Horizontal Inequalities."

26. Kalyvas, The Logic of Violence in Civil War.

27. Autesserre, The Trouble with the Congo, p. 43.

28. Kalyvas, The Logic of Violence in Civil War. 
that they want to further. Indeed, Kalyvas' work can be used to explain how an elite strongly motivated by political by interests or ideological convictions, with access to economic and military resources, can drag a country into civil war even if at the beginning there is no strong polarization among the people.

Research on 'horizontal inequalities' is also concerned about the interaction between the national and local level but it recognizes that, in some cases, the 'master cleavage' of the conflict can matter at both the local and national level. Socio-economic differences between groups with distinct identities (ethnic, religious, national groups) can trigger national level conflict, ${ }^{29}$ but the deliberate action of political elites is often necessary for this escalation to happen. ${ }^{30}$ The most dangerous cases are those where both communities and elites are excluded - when, for instance, representatives of a given community are formally or informally barred from key institutions such as the national government, the army or the top levels of the civil service, while communities are socio-economically disadvantaged and discriminated. ${ }^{31}$

Which mechanisms trigger the formation of horizontal inequalities? Scholars of African politics have looked at a particular type of political system that is often at the root of both elite and local level exclusion - neo-patrimonial politics. ${ }^{32}$ In neo-patrimonial systems, a facade of Western-style bureaucratic state coexists with patron-client networks. The existence of these networks creates a very strong bond between national politicians and local

29. Stewart, Horizontal Inequalities and Conflict; Cederman, Weidmann, and Gleditsch, "Horizontal Inequalities.”

30. Fearon and Laitin, "Violence and the Social Construction of Ethnic Identity."

31. Langer, "Horizontal Inequalities and Violent Conflict."

32. Erdmann and Engel, "Neopatrimonialism Reconsidered”; Daloz, ““ Big Men’ in Sub-Saharan Africa." 
communities. Politicians and high-ranking civil servants use access to public resources to entertain their clientele, rewarding local elites, such as customary and religious leaders, in exchange for their support. They are also expected to perform other actions benefitting their local constituencies, such as appointing clients to public servant jobs and allocating infrastructural works and developmental projects to their local strongholds. ${ }^{33}$ Neopatrimonialism can be inclusive, when different communities are equally represented in the central political system and profit to the same extent from their ties with political actors in the capital, but most often it encourages factionalization. ${ }^{34}$ Especially in times of economic crisis, it results into an intense competition between factions and communities over resources. When a politician from a given community is barred from political power in the capital, his clientele loses access to economic opportunities and public-sector jobs.

The link between patrons and local communities in a neo-patrimonial system is however not only of an economic nature. Clientelism and identity politics interact. ${ }^{35}$ Big men appeal to ethno-regional identities to reinforce their image as the champions for their community and mobilize their followers. They also exploit their intellectual superiority to influence the way in which the local communities perceive and interpret political developments at the national level. They represent the chain of connection between the rural areas and the educated urban elites and are often the first people to which local communities turn in order to have information on political events. ${ }^{36}$

33. Daloz, “ Big Men’ in Sub-Saharan Africa.”

34. Bach, "Patrimonialism and Neopatrimonialism."

35. Posner, "Regime Change and Ethnic Cleavages in Africa."

36. Olivier de Sardan, "The Eight Modes of Local Governance." 
Both clientelism and ethnic politics create thus 'perceptions of mutual interest' between the grassroots and the elite and establish 'vertical links of reciprocity'. ${ }^{37}$ This does not mean that local people have no agency but rather that the local is "never purely "local"'38 and that the actors who have the most influence on a given local community are often the ones with the closest ties to the national centre of power.

\section{Local peacebuilding after a victor's peace}

In short, the literature suggests that, in many post-conflict environments where politics is geared in a clientelist and neo-patrimonial fashion, local level peace will have a strong connection to national level peace.

This connection has particular consequences in countries where a conflict terminated with a military victory. Local peacebuilding efforts in these cases appear particularly problematic. In a 'victor's peace' there is neither reconciliation nor a power-sharing pact at the national level that grassroots efforts might uphold or complement. ${ }^{39}$ Typically, part of the leadership of the losing side will be killed, exiled, imprisoned, or otherwise constrained in its possibility to organize politically at the national level. A victor's peace reposes on a repressive or authoritarian model of conflict management, where the victor tries to prevent the vanquished from rearming and reorganizing by controlling or shaping space, economic

37. Lemarchand, "Political Clientelism and Ethnicity in Tropical Africa", p. 70.

38. Simons and Zanker. "Questioning the Local in Peacebuilding.", p. 15.

39. Piccolino, "Peacebuilding and statebuilding in post-2011 Côte d'Ivoire". 
resources and public discourse. ${ }^{40}$ In which ways can the lack of reconciliation at the national level impact local peace?

In order to show how a victor's peace can affect peacebuilding at the local level, complicating grassroots peacebuilding and reconciliation, and how the boundaries between the 'national' and 'local' are blurred, I list here three potential theoretical mechanisms linking national to local peace (Figure 1). I draw from the discussion in the previous paragraph, from my own observation of the Ivorian case and from secondary literature on other cases of 'victor's peace' ${ }^{41}$ My theoretical arguments are particularly applicable to countries like Côte d'Ivoire, where politics tend to be structured around clientelist networks with an ethnoregional or communitarian dimension. Some observations, however, are relevant also to other cases where peace is imposed by one of the warring parties through the defeat of the other.

\section{[Insert here Figure 1]}

1) The first mechanism relates to direct actions of vanquished political elites. Military victory in a civil war is typically attained when one of the two sides is able to control the capital city and the central state apparatus. However, while the defeated elite is unable to influence political events at the national level, its political leaders and militants might still have a grasp on some local constituencies and be able to control public discourse at the local level. These defeated politicians will strive to keep alive a counter-narrative of the past

40. Lewis, Heathershaw, and Megoran, "Illiberal Peace?”; Piccolino, "Winning Wars, Building (Illiberal) Peace?”.

41. For a discussion of other cases of 'victor's peace', see for instance Piccolino, "Winning Wars, Building (Illiberal) Peace?"; Jones, Soares de Oliveira, and Verhoeven, Africa's Illiberal StateBuilders; Lyons, "Victorious Rebels and Postwar Politics". 
conflict with respect to the one adopted by the national government and encourage the population to disengage from a state that they perceive as dominated by their enemies. In this process, they will have an interest in mobilizing ethnic identities.

2) The second and third mechanisms relate to the impact of exclusivist policies pursued by the victorious government. Victory leads to the victor monopolizing political power and excluding the vanquished. Especially in countries where politics is structured along identity cleavages (ethnic, religious, regional etc) the acts of persecution and humiliation that the leadership of the defeated side endures might be perceived by their constituencies as a persecution and humiliation against a whole community, even when this is not the intention of the incumbent government and when citizens are not persecuted.

3) In neo-patrimonial systems, the functioning of clientelist networks could exasperate the sense of exclusion of communities associated with the defeated party. Even if there is no explicit government policy discriminating against a particular group of people in access to jobs in the public sector and tenders, clientelist networks will tend to be dominated by politicians of the victorious side and, by consequence, by their ethno-regional constituencies. The constituencies of the losing side will thus experience decreased economic and social advancement opportunities.

In sum, one can expect that, after a victor's peace, local constituencies of the losing party will harbour deep feelings of resentment and mistrust towards the victorious elite that now controls the state. These feelings will also have an impact on their relationships with communities that they perceive aligned with the central government. Because these feelings originate from national level dynamics, they will be present even in sub-national areas that have not experienced particularly high levels of violence during the conflict.

In such a situation, programmes that aim to foster local peacebuilding might be caught into the struggle between irreconciled national elites. The national government might be 
interested in capturing these programmes and using them to appease the constituencies of the losing side and reassert its authority. However, it is in its interest to avoid that local peacebuilding initiatives become an occasion to voice criticism against the government and/or give space to counter-narratives about the past conflict that contradict the official view. On the other hand, the opposition might encourage the population to boycott activities that they see as propaganda efforts from the government, and not genuine initiatives aimed at fostering dialogue and reconciliation.

In the next section, I analyze how local peacebuilding programmes have been affected by the national level situation in post-conflict Côte d'Ivoire. I first look at how a discourse emphasizing the important of local peacebuilding emerged in Côte d'Ivoire. I then explore the three different mechanisms that link national and local peace, relying on interviews and focus groups with Ivorians of different ethnic background and social condition, especially Ivorians living in the South West areas, the strongholds of the former Gbagbo regime. My interviews reveal how relationships between communities are hampered by the lack of reconciliation at the national level and the unwillingness or inability of the Ivorian government to solve key national level problems.

\section{Victor's peace and local peacebuilding in Côte d'Ivoire}

\section{From politico-military crisis to 'victor's peace'}

After the death in 1993 of first president and 'father of the nation' Félix Houphouët-Boigny Côte d'Ivoire, once heralded as an African 'economic miracle', got engulfed in a long economic and political crisis. Political instability culminated in 2002 in a failed coup d'état 
that led to the occupation of the Northern half of the country by the armed rebellion of the Forces Nouvelles (FN, 'New Forces'). ${ }^{42}$ Much of the crisis revolved around the ethnopolitical cleavage between Ivorians of Northern ethnicities (often called dioula in everyday discourse) and the so-called 'autochthonous' ethnic groups from the South West of the country (the populations belonging to the Krou language group, such as the bété and guéré). ${ }^{43}$ During the Houphouët-Boigny era, Ivorians from the Northern and Central part of the country migrated massively to the South West, which has become the main centre of cocoa production. To this internal migration, one has to add migration from neighbouring Burkina Faso and Mali, whose inhabitants share many cultural and linguistic features with Northern Ivorians. This led to intense competition over land and tensions between the 'allochtonous' and the indigenous population of the South West. ${ }^{44}$

Although migration and land disputes fuelled community tensions, the Ivorian crisis was hardly the result of local level problems only. National level development and the Ivorian political elite played a key role in the violent escalation of inter-ethnic competition. ${ }^{45}$ With the reintroduction of multi-party politics in 1990 and the death of Houphouët-Boigny, political competition intensified between three key political leaders - Henri Konan Bédié, who became president in 1995 and was subsequently deposed by a military coup, Laurent Gbagbo, elected in 2000, and Alassane Ouattara, who was prime minister at the time of

42. Akindès, The Roots of the Military-Political Crises in Côte d'Ivoire; Marshall-Fratani, "The War of 'Who Is Who'."

43. Marshall-Fratani, "The War of 'Who Is Who'.”

44. Akindès, The Roots of the Military-Political Crises in Côte d'Ivoire; Marshall-Fratani, "The War of 'Who Is Who': Autochthony, Nationalism, and Citizenship in the Ivoirian Crisis.”

45. Langer, "Horizontal Inequalities and Violent Conflict"; Akindès, The Roots of the MilitaryPolitical Crises in Côte d'Ivoire. 
Houphouët-Boigny's death. The three politicians instrumentalized identity politics and came to be seen as the representatives of different ethno-regional groups, each representing roughly one third of the electorate: Ouattara of the 'Northerners', Bédié of the baoule from central Côte d'Ivoire and Gbagbo of the 'autochthonous' - those of the South-West and of some other areas of Southern Côte d'Ivoire. Controversies about his nationality prevented twice Ouattara from running for president. ${ }^{46}$ The disqualification of Ouattara and the feeling of being marginalized and deprived of their nationality by president Laurent Gbagbo led many Northern Ivorians to support the 2002 rebellion. $^{47}$

Several attempts were made in order to negotiate an end to the conflict, and the Ouagadougou Political Agreement (OPA) of 2007 seemed to represent a breakthrough. ${ }^{48}$ The 2010 troubled presidential elections however re-ignited the conflict, which eventually ended in 2011 when Alassane Ouattara assumed power. Ouattara's electoral success was due to the creation of the Rassemblement des Houphouetistes pour la Democratie et la Paix (RHDP), an alliance formed by Ouattara's Rassemblement des Républicains (RDR), the former single party Parti Démocratique de la Côte d'Ivoire (PDCI) of Bédié and other minor political forces. However, Ouattara also needed the military support of the FN and of the international peacekeeping forces in order to defeat Laurent Gbagbo and take power. ${ }^{49}$

What characterizes the Ivorian post 2011 transition is the clear existence of a victorious and a defeated side. Gbagbo, who refused to relinquish power, was arrested and deferred to the International Criminal Court (ICC) in The Hague, where he has remained in

46. Dembele, "Côte d'Ivoire: La Fracture Communautaire."

47. Marshall-Fratani, "The War of 'Who Is Who'."

48. Charles and Handy. "L'Accord Politique de Ouagadougou".

49. Piccolino, "David against Goliath in Côte d'Ivoire?". 
detention until his acquittal in January 2019. ${ }^{50}$ Many of his followers were detained for more or less long periods after 2011, including former First Lady Simone Gbagbo and the president of Gbagbo’s party Front Populaire Ivoirien (FPI), Pascal Affi N'guessan.

For several years, the FPI leaders who were not jailed seemed entrapped in a rhetoric of victimization and systematically boycotted parliamentary and local elections. Things have become more complex with the release of Affi N'guessan from jail in 2013. His determination to run for president in the 2015 elections encountered the opposition the rest of the leadership. A group of party officials who had been members of the FPI since its foundation rallied around vice-president Abdourahmane Sangaré, provoking a schism. ${ }^{51}$ Although Affi N'guessan was able to run as official FPI candidate, the 'dissidents' received the backing of Laurent Gbagbo himself from his Hague detention. Comparing the results of the 2015 presidential elections to those of 2010 , it is possible to estimate that about $25 \%$ of the voters felt excluded from the political game and followed the appeal to boycott the elections. ${ }^{52}$ The same pattern continued after 2015, with the dissident wing of the FPI also boycotting the 2016 legislative elections and the 2018 local elections and the 'official' FPI participating but receiving a meagre share of the votes.

The political situation started to shift in 2018, with the approaching of the 2020 presidential elections and the uncertainty about who will run as RHDP candidate. The government alliance collapsed due to Ouattara's determination to transform the RHDP in a single political party and to the refusal of Bédié and of the majority of the PDCI to adhere to

50. International Criminal Court, "ICC Trial Chamber I acquits Laurent Gbagbo and Charles Blé Goudé".

51. Piccolino, "One Step Forward, Two Steps Back?”.

52. Calculation based on République de Côte d'Ivoire, Second tour de l'élection du Président de la République, and Abidjan.net, Election du Président de la République. 
it. At the moment in which this article is being written (January 2019), the political landscape is still in flux, and Gbagbo's release could compromise the prospects for a new PDCI-FPI alliance.

The year 2018 also saw Ouattara granting an amnesty to eight hundred people detained or condemned for crimes against state security, including former First Lady Simone Gbagbo. ${ }^{53}$ The amnesty responded to some of the grievances of the 'Gbagbo camp' here discussed, but it is difficult at the moment to evaluate its impact on local peacebuilding. The release of political prisoners did not put an end to the division of the FPI party and might indeed have been intended to prevent its reunification, given the strong antipathy between Simone Gbagbo and Affi N'guessan. Sangaré's death short after the amnesty contributed to complicate the situation. The impact of Gbagbo's release is also uncertain, and it is unlikely to dissipate the perception of uneven international justice, given the lack of prosecution against pro-Ouattara personalities and the long preventive detention that Gbagbo and his close associate Charles Blé Goudé endured.

In conclusion, the 2011 end of the conflict left a country divided and with several issues unresolved. Transitional justice was unbalanced and, while numerous pro-Gbagbo militants were detained for real or presumed crimes, war crimes committed by the proOuattara side have, up to the date, never been prosecuted. Under the Ouattara presidency, democratization was hampered by the fact that the RHDP de facto monopolized political power, while part of the opposition persisted in boycotting the elections. By opening the political space, the reordering of political alliances happening in 2018-2019 could have in the long term a positive impact for the country's democracy, but in February 2019 it is still too early to tell.

53. Piccolino, "Côte d'Ivoire's president announced an amnesty program". 


\section{The rise of 'social cohesion'}

Since the outbreak of the crisis, Côte d'Ivoire saw the rise of a discourse emphasizing the necessity to promote 'social cohesion' at the local level through programmes targeting local ethnic communities. This rhetoric pre-dates the Ouattara presidency, as it was first introduced by the international community during the 2002-2010 peace process. International peacebuilders, under the lead of the United Nations Operation in Côte d'Ivoire (UNOCI) set the blueprint for 'social cohesion'. Quick Impact Projects (QIP), endowed with a budget of more than two million euro, aimed to satisfy the urgent socio-economic needs of the population, but also to 'reinforce social cohesion as a follow up to inter-community dialogue'. ${ }^{4}$ UN Civil affairs officers were also involved in other activities targeted at improving dialogue between local communities, such as workshops where participants were asked to list 'the main causes of tensions, mistrust and lack of confidence between the people from different communities', propose 'activities to improve cohabitation' and 'recommendations for the authorities'. ${ }^{55}$ A community driven development approach supposed to contribute to the 'restoration of social capital and social cohesion' ${ }^{56}$ also underpinned the Post-Conflict Assistance Project (PCAP), implemented in partnership by the World Bank and the Prime Minister office after the conclusion of the OPA in 2007.

After 2011, the Ivorian government launched a series of peacebuilding initiatives. The first and most ambitious, however, the Commission Dialogue, Vérité et Réconciliation (CDVR), created in 2011 with a mandate that included the truth seeking, dialogue and hearing with the victims of the crisis, felt victim of exaggerated expectations, faulty

54. UNOCI, "Civil Affairs".

55. UNOCI, "Activity report"

56. World Bank, "Project Information Document (PID)". 
leadership but also of the government's dwindling support. ${ }^{57}$ The government made public its final report with a delay of two years, in a version that has been heavily expunged of its sensitive passages. ${ }^{58}$

While the CDVR was struggling, Ivorian government officials increasingly turned to the rhetoric of 'social cohesion', which was portrayed by Ouattara as a crucial goal of his presidency. ${ }^{59}$ In 2012, social cohesion got its official governmental endorsement with the creation of the Programme Nationale de Cohésion Sociale (PNCS). The PNCS was subsequently expanded and extended until 2020, under the new label of Programme National de Réconciliation et de Cohésion Sociale (PNRCS). The programme brought under a single umbrella a series of initiatives launched by international peacebuilders, the Ivorian government and NGOs. ${ }^{60}$ The belief that communities, local leaders and everyday citizens have the responsibility to 'ensure that the achievements of the programme are permanently sustained, ${ }^{61}$ underpins the PNCS.

What did make 'social cohesion' so attractive to the Ivorian government, as well as to international peacebuilders? Taking a cynical view, it can be argued that focusing on small scale projects targeting local communities has freed both national and international actors from the imperative of addressing politically charged national level issues revolving around transitional justice and democratization. The PNRCS's mission focuses on 'peace and the reduction of tensions between different communities'... 'peace and harmony among the

57. Lopes, "La Commission Dialogue Vérité et Réconciliation en Côte d'Ivoire."

58. The author had the opportunity to compare a confidential summary of the uncensored report and the version published (CDVR, "Rapport Final").

59. Présidence de Côte d'Ivoire, "Message du Nouvel An 2018".

60. PNCS, "Réalisations 2015 en Matière de Cohésion Sociale".

61. Interview with PNCS official, 27 May 2015, Abidjan. 
peoples', ${ }^{62}$ neglecting the political elites that represent, or claim to represent, these communities. There is no discussion of the impact that the boycott of elections by the proGbagbo opposition and the mistrust of Gbagbo's supporters in the electoral process have on 'social cohesion'. The programme laments the 'fragmentation of interventions and lack of synergies $^{\prime 63}$ of the transitional justice architecture, but fails to address the politically-driven lack of clarity about its mission, focusing almost exclusively on improving the delivery of reparations to victims. ${ }^{64}$

In the next paragraph, I discuss how the defeated pro-Gbagbo side pushed back since 2011 against the Ivorian government-sponsored version of 'social cohesion'. I show, drawing from interviews and focus groups with Ivorian citizens, that the pro-Gbagbo view was endorsed by many 'locals' and that 'social cohesion' at the local level was often undermined by unresolved national level questions. The very narrative that the key to peace is to be found at the local level was contested by a section of the Ivorian population.

\section{The point of view of the citizens 'from below'}

Can the promotion of social cohesion at the local level work in the context of a victor's peace and in the absence of elite level reconciliation? I discussed in the previous section three mechanisms that undermine local peacebuilding after a conflict terminated with a military victory (Figure 1). Following the first mechanism, defeated politicians use their influence on

62. Ministère de la Solidarité, Programme National de Réconciliation, Introduction, p.5.

63. Ministère de la Solidarité, Programme National de Réconciliation, 'Contexte et justification du programme', p.18.

64. Ministère de la Solidarité, Programme National de Réconciliation, 'Structure du Programme National de Réconciliation et Cohésion Sociale', p. 23. 
local communities to contest the narrative of the victorious elite and to undermine state-driven peacebuilding initiatives.

The mechanism can be illustrated with reference to the Ivorian case. Since 2011, the pro-Gbagbo side developed its own counter narrative of the Ivorian crisis and the 2011 events. In this narrative, Laurent and Simone Gbagbo are portrayed as two heroic anti-colonial combatants, who ended up in prison because they were victims of a plot orchestrated by France with the complicity of UNOCI and of Côte d'Ivoire's neighbours. ${ }^{65}$ Pro-Gbagbo militants claim that the president of the Independent Electoral Commission (IEC) manipulated the election results in 2010. The liberation of Gbagbo was seen as a key pre-condition for peace and reconciliation. ${ }^{66}$

With some reason - although often overstating the case - Pro-Gbagbo politicians also accuse Ouattara and the RHDP of authoritarian tendencies. Between 2014 and 2017 the dissident wing of the FPI published yearly reports with detailed information about 'political prisoners' - pro-Gbagbo militants held in jail - and vocally denounced the 'victor's justice' of the government. ${ }^{67}$ FPI politicians also contested the composition of the IEC, questioned the transparency of the electoral process ${ }^{68}$ and accused the Ivorian government of ethnic based discrimination in appointing high ranking civil servants. ${ }^{69}$

The activism of pro-Gbagbo leaders has had a significant impact on local peacebuilding. Pro-Gbagbo politicians encouraged their supporters to disengage from stateled initiatives and to be suspicious of the rhetoric of reconciliation and 'social cohesion',

65. Piccolino, "David against Goliath in Côte d'Ivoire?".

66. Miquel and Rosenberg, "Shadow of Gbagbo".

67. Gbagbo, "Rapport n.1-2017: interrogations sur la cohésion nationale".

68. Garat, 'Invité Afrique'.

69. Akindès, "'On ne mange pas les ponts et le goudron"'. 
which they saw as a tool in the hands of the government. While the dissident FPI promoted the boycott of various electoral consultations after 2011, pro-Gbagbo leaders had a mixed relationship with the CDVR. They initially encouraged their followers to boycott the hearings, but they then partially stepped back when they realized that the CDVR could give to victims of human rights violations committed by the pro-Ouattara side an occasion to be heard. For many former Gbagbo voters at the grassroots level, following the political direction of pro-Gbagbo politicians became a way to assert their agency vis a vis to the Ouattara government. They did so by deploying their 'weapons of the weak' - electoral abstention, disengagement or employing mechanisms that the government believed it could control, such as the CDVR, to criticize the ruling party.

I draw here from field research conducted in 2015 to show how the narrative of the pro-Gbagbo side resonated at the grassroots level and cleavages between the pro-Gbagbo and the pro-Ouattara side affected local peacebuilding. I am using primarily evidence from twenty focus groups conducted between May and June 2015, eight in four different neighbourhoods of Abidjan and twelve in the South West of the country (the cities of Daloa, Gagnoa and Duékoué). The latter area is considered the stronghold of the FPI and community divisions between 'autochthonous' ethnic groups and internal and external migrants are particularly high. The focus group participants were Ivorians from different social groups female traders, leaders of grassroots associations, drivers, students, teachers - as well as persons belonging to categories particularly implicated in the crisis - former combatants and former internally displaced persons. During the same period, I also conducted about ninety interviews with elite actors such as Ivorian politicians, civil servants, international officials, experts and NGO leaders.

Ivorians interviewed generally agreed that peace and social cohesion at the local level are important and that social cohesion was only partly attained with the official end of the 
crisis in 2011. Tensions and mistrust persisted and affected the everyday experience of many Ivorians. ${ }^{70}$ Ethnic cleavages continued to divide the Ivorian society, with 'Northerners' automatically perceived as being pro-Ouattara and the 'Western autochthonous people' perceived as pro-Gbagbo. ${ }^{71}$ However, local level tensions and mistrust between communities were deeply interconnected with national level problems.

While interviewing non-elite Ivorians, it was not difficult to see many cases where they reproduced all or parts of the FPI narrative. Some themes - for instance the question of 'neo-colonialism' and Western interference - had an echo predominantly among educated, urban-based Ivorians, such as students and teachers. ${ }^{72}$

On the other hand, the idea that the liberation of Gbagbo and of the political prisoners should be a precondition for reconciliation had also a strong echo among the rural communities that were the main target of many local peacebuilding activities. The words of a planter from a bété (Gbagbo's ethnic group) village are a typical statement of this position:

70. Focus group, market women in the Abobo neighbourhood, Association des Femmes la solidarité, Abobo, Abidjan, 20 May 2015; Focus group, youth from the Yao Sehi neighbourhood, Comité de Coordination de la Société Civile de Youpougon, Yopougon, Abidjan, 21 May 2015; Focus group, representatives of students' syndicates, Université Félix Houphouët-Boigny, Cocody campus, Abidjan, 27 May 2015; Focus group, representatives of associations of autochthonous women, Souspréfecture office, Gagnoa, 13 July 2015.

71. Focus group, market women from the Abobo neighbourhood, May 20, 2015, Association des Femmes la solidarité, Abobo, Abidjan; Focus group, youth from Yao Sehi neighbourhood, May 21, 2015, Civil Society Committee of Youpougon, Yopougon, Abidjan.

72. Focus group, representatives of student unions, May 27, 2015, Université Félix HouphouëtBoigny, Cocody campus, Cocody, Abidjan. 
So, when we talk about a crisis, it comes from both sides. When it ends, everyone should be free in order to make peace... So, if they really want reconciliation, they just have to free all those who are in prison. All of them. Without exceptions. ${ }^{73}$

The fact that many former Gbagbo electors are convinced that the liberation of Gbagbo and of the political prisoners should be a precondition for local reconciliation often hampered efforts at local peacebuilding. In a focus group with a federation of women associations in the Daloa area, which aims to bring together women from both pro-Ouattara and pro-Gbagbo communities and build 'social cohesion', the leaders of the association complained that women from autochthonous ethnic groups were often disengaged.

For a celebration, we went to Zakoua [a village in the area], we brought together the women, and while I was talking one of them shouted: 'Free Gbagbo first!'... These are the kind of issues we have to deal with all time... You call the people, they refuse to come because they are telling themselves that there are other people who are kept in prison... ${ }^{74}$

How do narratives of victimization and frustration with the government trickled down from the elite to the community level? In some cases, following the first mechanism outlined at the beginning (Figure 1), politicians intervened directly in local communities in order to undermine 'social cohesion' and stir inter-community tensions. Former Gbagbo voters in both urban and rural areas were in various ways exposed to the discourse of the pro-Gbagbo elite,

73. Focus group, planters and villagers, June 27, 2015, Village of Seria, Daloa; Interview with NGO official, May 26, 2015, Abidjan.

74. Focus group, Federation of women associations of the Bas Sassandra region, June 17, 2015, Townhall of Daloa, Daloa. 
who operated under the clout of the two wings of the FPI or within civil society organizations such as trade unions, student associations and ethnic associations.

In rural areas, the influence of the FPI and other pro-Gbagbo organization was usually relayed through the local 'cadres' - a word used for politicians, upper ranking civil servants and businessmen. The cadres retain a strong influence on the village where they are born or where their family is from, even if they have moved. The cadres and their collaborators in the village are regularly consulted about important decisions and political events. In pro-Gbagbo communities, this influence was often used to hamper activities supposed to advance social cohesion.

As a local NGO officer puts it...

... When you go to a village to meet the local youth or to do awareness-raising activities, as soon as you turn your back, they take the telephone to call the cadre of the village. They tell him, 'this organization has come to the village, they tell us to do this or that. And he, who rarely comes to the village, or comes only when there is a funeral, says 'Don't go ahead with what they propose. Do not listen to these folks'. ${ }^{75}$

Why do local people follow their political representatives and endorse their narratives? In order to understand it, we should consider the two additional mechanisms previously described: 2) the mechanisms of ethnic identification and 3) the clientelistic nature of Ivorian politics (Figure 1). Especially in rural areas, acts of persecution against militants who are co-ethnics and perceived as the political representatives of an ethnic community, are interpreted as an attack to the entire community. When discussing the ordeal of the political

75. Focus group, former internally displaced persons, June 30, 2015, Headquarters ONG Bonne Action, Duékoué. 
prisoners, villagers from the autochthonous South Western communities used terms such as 'brothers', 'sons' 'daughters' and 'relatives' for their co-ethnics who are in prison. For instance, a grassroots organizer who was trying to convince a bété woman to enrol for elections got the reply: 'my son is in prison, my daughter is in prison, I am not interest in getting on the electoral list, whom could I vote for?...' ${ }^{76}$ For a guéré widow, the fact that she had benefited from a government resettlement programme seemed secondary with respect to her sadness for 'our relatives who are in prison'. ${ }^{77}$

Especially in the countryside, pro-Gbagbo leaders were seen as relatives also for their role in clientelist networks, for providing for their communities. As a villager put it: 'That's your family, your brother who gives you to eat, if you are skint, he helps you. They took him away and locked him up, can you sit down and laugh?'78 In the words of two other women from the Gagnoa area, the liberation of all political prisoners was necessary 'because our relatives are all connected in a way or another to those persons... if they can work, they can help their families. ${ }^{79}$

Interestingly, in interviews conducted in cities, the existence of clientelist networks was acknowledged, but in a different way. While villagers talked about 'parents' who fulfil their mission to provide for their relatives, urban dwellers were often critical towards clientelistic relationships, aware of their role in stirring violence, and portrayed them in ways

76. Focus group, Federation of women associations of the Bas Sassandra region, June 17, 2015, Townhall of Daloa, Daloa.

77. Focus group, former internally displaced persons, June 30, 2015, Headquarters ONG Bonne Action, Duékoué,

78. Focus group, planters and villagers, June 27, 2015, Village of Seria, Daloa

79. Focus group, representatives of associations of women from the autochthonous communities, July 13, 2015, Sous-préfecture office, Gagnoa. 
that were more crudely economic and exploitative. For instance, for a market trader based in a popular neighbourhood of Abidjan, 'if people can eat normally, there won't be any disputes... It is poverty. You follow the party that comes and gives you 20000 CFA. That's what causes the war'. ${ }^{80}$ For another woman, who leads a grassroots association in the same neighbourhood, economic security is 'very important for peace, because, if you have a proper accommodation, you do not need to sleep in someone else's living room. If you need to stay in someone else's living room, you sleep there, you are obliged to do what he wants' ${ }^{81}$

In such a clientelist system that is fragmented along ethnic lines, not only common people feel that they are not anymore 'provided for' once their ethnic leaders are in prison or excluded from power. They also feel that another group has privileged access to state patronage. For instance, youth in an Abidjan neighbourhood considered pro-Gbagbo expressed their feeling that 'ethnic favouritism' benefitting 'Northerners' was common and that 'if there is a public competition, you can be turned down if your name sounds from the West, even if you are qualified'. ${ }^{82}$

Some supporters of the defeated side openly contested the government's narrative that placed the responsibility to work for reconciliation and 'social cohesion' on everyday Ivorians and local communities. They considered inter-community relationships in their village or town quite good, and believed that the residual mistrust that existed was a

80. Focus group, market women from the Abobo neighbourhood, May 20, 2015, Association des Femmes la solidarité, Abobo, Abidjan.

81. Focus group, representatives of women associations, May 19, 2015, Centre Sociale de Abobo, Abobo, Abidjan.

82. Focus group, youth from Yao Sehi neighbourhood, May 21, 2015, Civil Society Committee of Youpougon, Yopougon, Abidjan. 
reflection of the lack of reconciliation at the national level and a consequence of the actions of the government.

As a member of a pro-Gbagbo association from Gagnoa puts it, 'the root of the discontent, when they talk about discontent, is at the national level. They [the government] themselves know that their behaviour is not the sort of behaviour that can bring peace. ${ }^{83} \mathrm{~A}$ villager similarly expresses the idea that the main political leaders, not local people, should bear responsibility for reconciliation.

A souspréfect was telling me, there are two people [Alassane Ouattara and Laurent Gbagbo] who are in conflict, once the two make it up, for all those who are behind them everything will be finished, we won't talk about it anymore... So, it is only them who can bring reconciliation to Côte d'Ivoire. ${ }^{84}$

In conclusion, while there were problems at the local level in Côte d'Ivoire that can fuel divisions between communities (for instance, disputes around land tenure) a lot of the obstacles to a more meaningful peacebuilding were situated at the level of national politics (biased transitional justice; flawed democratization; ethnic favouritism). Local communities are connected to the national level both by a web of clientelist networks and by sociopsychological mechanisms of alignment and identification with their national representatives. For this reason, while there are actions that can be taken to improve inter-communities

83. Focus group, representatives of associations of the autochthonous community, July 11, 2015, Restaurant "Le Talier du chef", Gagnoa.

84. Focus group, planters and villagers, June 27, 2015, Village of Seria, Daloa; Interview with NGO official, May 26, 2015, Abidjan. 
relationships, the idea that the 'local' can be the key to peace is misleading - and is seen as misleading by many of the locals themselves.

\section{Conclusion}

In the last ten years, both academics and policy makers have insisted on the importance of the local level. Some have gone as far as to present the 'local' as the true key for peacebuilding. However, local peace is intimately linked to national level peace. In countries where the conflict terminated with the victory of one of the warring parties, rather than with a compromise, lack of reconciliation between national leaders, failed democratization and onesided transitional justice have an impact on local peace, producing tensions between communities. Ethnic patronage systems exacerbate this tendency by keeping local communities connected to national level 'big men'.

In these post-conflict settings, local peacebuilding activities become, at least rhetorically, an attractive approach for both the national government and international donors. This is not because of local peacebuilding's effectiveness, but because it allows them to claim that they are working towards peacebuilding, while not addressing national level issues that are too difficult or too sensitive, or that could endanger the interests of the power holders.

This has been the case in Côte d'Ivoire, where 'social cohesion' programmes, mostly targeting local communities, have become popular and have been actively promoted by the Ivorian government after 2011. In the meantime, the government has been either unwilling or unable to address key national level issues. It has kept pursuing one sided transitional justice and it has not managed to persuade an important part of the political opposition to participate in the elections. 
The Ivorian case shows that the local peacebuilding agenda is prone to co-optation by authoritarian and semi-authoritarian regimes. On some respects, the local turn might represent a regression, rather than a progressive step, with respect to the liberal peacebuilding agenda. The latter, even with its evident limits, had at least the merit to put at the centre stage the crucial problem of the legitimacy of political power. By contrast, the rhetoric of local peacebuilding can be used to justify a shift to low-profile activities that allows both the government and the donors to avoid controversial political issues potentially threatening their power.

However, as political violence stems from the interaction between national elites and local communities, so does peacebuilding. The attainment of a peace that is deeper and more meaningful than just the absence of violence requires actions at both levels. While the 'locals' are not necessarily supporters of liberal peacebuilding, my interviews suggest that a political system that is inclusive and can manage conflict at the elite level can also have positive effects on local peace. 
Akindès, Francis. The Roots of the Military-Political Crises in Côte d'Ivoire (Uppsala:

Nordiska Afrikainstitutet, 2004).

Akindès, Francis. “'On ne Mange pas les Ponts et le Goudron': Les Sentiers Sinueux d'une Sortie de Crise en Côte d'Ivoire." Politique Africaine, no. 4 (2017): 5-26.

Allouche, Jeremy and Paul Jackson. "Zones of Peace and Local Peace Processes in Côte d'Ivoire and Sierra Leone", Peacebuilding, advance access (2018): DOI:10.1080/21647259.2018.1491276.

Autesserre, Séverine. The Trouble with the Congo: Local Violence and the Failure of International Peacebuilding (Cambridge: Cambridge University Press, 2010).

Autesserre, Séverine. “There's Another Way to Build Peace. And it doesn't Come from the Top Down." Monkey Cage, The Washington Post, October 232018

https://www.washingtonpost.com/news/monkey-cage/wp/2018/10/23/theres-another-way-tobuild-peace-and-it-doesnt-come-from-the-top-down/?utm term=.c8dd6ed22a51 (accessed November 21, 2018).

Autesserre, Séverine. "The Crisis of Peacekeeping: Why the UN Can't End Wars", Foreign Affairs, 98, no. 1, (2019): 101.

Bach, Daniel C. "Patrimonialism and Neopatrimonialism: Comparative Trajectories and Readings." Commonwealth \& Comparative Politics 49, no. 3 (2011): 275-94.

Cederman, Lars-Erik, Nils B. Weidmann, and Kristian Skrede Gleditsch. "Horizontal Inequalities and Ethnonationalist Civil War: A Global Comparison." American Political Science Review 105, no. 3 (2011): 478-95.

Daloz, Jean-Pascal. “'Big Men’ in Sub-Saharan Africa: How Elites Accumulate Positions and Resources." Comparative Sociology 2, no. 1 (2003): 271-85.

Dembele, Ousmane. "Côte d'Ivoire: La Fracture Communautaire.” Politique Africaine, no. 1 (2003): $34-48$. 
Erdmann, Gero, and Ulf Engel. "Neopatrimonialism Reconsidered: Critical Review and Elaboration of an Elusive Concept." Commonwealth \& Comparative Politics 45, no. 1 (2007): 95-119.

Ernstorfer, Anita, Diana Chigas, and Hannah Vaughan-Lee. "From Little to Large: When Does Peacebuilding Add Up?" Journal of Peacebuilding \& Development 10, no. 1 (2015): $72-77$.

Fearon, James D., and David D. Laitin. "Violence and the Social Construction of Ethnic Identity." International Organization 54, no. 4 (2000): 845-77.

Garat, Frédéric, "Invité Afrique: 'Pour ramener la confiance, il faut une élection crédible"”, interview with Aboudramane Sangaré, Radio France Internationale, February 19, 2018. http://www.rfi.fr/emission/20180219-cote-ivoire-ramener-confiance-election-credible (accessed May 19, 2018).

Gbagbo, Michel K. Rapport n.1-2017: Interrogations sur la Cohésion Nationale, Front Populaire Ivoirien, General Secretariat, January 2017. http://lecombattant.canalblog.com/archives/2017/02/01/34877791.html (accessed May 7, 2017).

Heathershaw, John. Post-Conflict Tajikistan: The Politics of Peacebuilding and the Emergence of Legitimate Order (London: Routledge, 2009).

Jones, Will, Ricardo Soares de Oliveira, and Harry Verhoeven. "Africa's Illiberal StateBuilders” (Working Paper 89, Refugee Studies Centre, University of Oxford, Oxford 2012). Kalyvas, Stathis N. The Logic of Violence in Civil War. Cambridge; New York: Cambridge University Press, 2006.

International Criminal Court (ICC), "ICC Trial Chamber I acquits Laurent Gbagbo and Charles Blé Goudé from all charges", Press Release ICC-CPI-20190115-PR1427, 15 January $2019<$ https://www.icc-cpi.int/Pages/item.aspx?name=pr1427> (accessed February 9, 2019). 
Langer, Arnim. "Horizontal Inequalities and Violent Conflict: the Case of Côte d'Ivoire" (Working Paper no 13, Centre for Research on Inequality, Human Security and Ethnicity (CRISE), University of Oxford, Oxford, 2004).

Lederach, John Paul. Building Peace: Sustainable Reconciliation in Divided Societies. United States Institute of Peace Press, 1997.

Lemarchand, René. "Political Clientelism and Ethnicity in Tropical Africa: Competing Solidarities in Nation-Building." American Political Science Review 66, no. 1 (1972): 68-90. Lewis, David, John Heathershaw, and Nick Megoran. "Illiberal Peace? Authoritarian Modes of Conflict Management." Cooperation and Conflict (Published online in advance access: April 23, 2018), https://doi.org/10.1177/0010836718765902.

Lopes, Daniel. La Commission Dialogue Vérité et Réconciliation en Côte d'Ivoire: la réconciliation n'a pas eu lieu (Report, Groupe de Recherche et d'Information sur la Paix et la Sécurité (GRIP), Bruxelles, 30 June 2015).

Lyons, Terrence. "Victorious Rebels and Postwar Politics." Civil Wars 18, no. 2 (2016): 16074.

Mac Ginty, Roger, and Oliver P. Richmond. "The Local Turn in Peace Building: A Critical Agenda for Peace.” Third World Quarterly 34, no. 5 (2013): 763-83.

Mac Ginty, Roger. "Where Is the Local? Critical Localism and Peacebuilding.” Third World Quarterly 36, no. 5 (2015): 840-56.

Marshall-Fratani, Ruth. "The War of 'Who Is Who': Autochthony, Nationalism, and Citizenship in the Ivoirian Crisis." African Studies Review 49, no. 2 (2006): 9-43.

Miquel, Tristan, and Sophie Rosenberg, "Shadow of Gbagbo over Côte d'Ivoire Elections", in: JusticeInfo.net, 23 October 2015. www.justiceinfo.net/en/tribunals/icc/2655-shadow-ofgbagbo-over-côted-ivoire-elections.html (accessed December 3, 2015). 
Ouattara, Alassane, Message du nouvel an 2018 de S.E.M. Alassane Ouattara, Presidency of Côte d'Ivoire, December 31, 2017. http://www.presidence.ci/message-du-nouvel-an-2018-des-e-m-alassane-ouattara/ (accessed May 25, 2018).

Olivier de Sardan, Jean-Pierre. "The Eight Modes of Local Governance in West Africa." IDS Bulletin 42, no. 2 (2011): 22-31.

Piccolino, Giulia. "David against Goliath in Côte d'Ivoire? Laurent Gbagbo's War against Global Governance.” African Affairs 111, no. 442 (2012): 1-23.

Piccolino, Giulia. "Winning Wars, Building (Illiberal) Peace? The Rise (and Possible Fall) of a Victor's Peace in Rwanda and Sri Lanka." Third World Quarterly 36, no. 9 (2015): 177085.

Piccolino, Giulia. 'One Step Forward, Two Steps Back? Côte d'Ivoire's 2015 Presidential Polls', Africa Spectrum 51, no. 1 (2016): 97-110.

Piccolino, Giulia. "Peacebuilding and statebuilding in post-2011 Côte d'Ivoire: A victor's peace?" African Affairs 117, no. 468 (2018): 485-508.

Piccolino, Giulia, 'Côte d'Ivoire's President Announced an Amnesty Program. Is this the end of a 'victor's peace'?', Monkey Cage blog, Washington Post, August 15, 2018, https://www.washingtonpost.com/news/monkey-cage/wp/2018/08/15/ivory-coasts-presidentannounced-a-new-amnesty-program-is-this-the-end-of-a-victorspeace/?utm_term $=.25 \mathrm{cb} 7 \mathrm{fc} 97 \mathrm{aa} 4$ (accessed 29 November 2018).

Posner, Daniel N. "Regime Change and Ethnic Cleavages in Africa." Comparative Political Studies 40, no. 11 (2007): 1302-27.

Republic of Côte d'Ivoire, Programme National de Réconciliation et de Cohésion Sociale (PNRCS) 2016-2020, Ministère de la Solidarité, de la Cohésion Sociale et de l'Indemnisation des Victimes, 2015, Abidjan. 
Republic of Côte d'Ivoire, Second tour de l'élection du Président de la République, Scrutin du 28 Novembre 2010, Commission Electorale Indépendante, and Abidjan.net, Election du Président de la République, Scrutin du 25 Octobre 2015, Résultats fournis par la Commission Electorale Indépendante, 27 October $2015 . \quad<$ http://abidjan.net/ELECTIONS/presidentielle/2015/resultats.html > (accessed April 11, 2017).

Republic of Côte d'Ivoire. Réalisations 2015 en Matière de Cohésion Sociale, de Réconciliation Nationale et d'Indemnisation des Victimes des Crises Survenues: Rapport General, Programme National de Cohésion Sociale (PNCS), December 2015.

Republic of Côte d'Ivoire, Rapport Final, Commission Dialogue, Vérité et Réconciliation (CDVR), Abidjan, published on 26 Octobre 2016 and dated December 2014, $<$ https://www.gouv.ci/doc/presse/1477497207RAPPORT\%20FINAL_CDVR.pdf $>$ (accessed March 13, 2017).

Richmond, Oliver. A Post-Liberal Peace (London: Routledge, 2012).

Simons, Claudia and Franzisca Zanker, "Questioning the Local in Peacebuilding" (Working Paper 10, German Research Foundation, Programme Adaptation and Creativity in Africa. Leipzig and Halle 2014).

Simons, Claudia, Franzisca Zanker, Andreas Mehler, and Denis M. Tull. "Power-Sharing in Africa's War Zones: How Important Is the Local Level?” The Journal of Modern African Studies 51, no. 4 (2013): 681-706.

Stearns, Jason. "The Trouble with the Congo: Local Violence and the Failure of International Peacebuilding.” Review of African Political Economy 40, no. 135 (March 1, 2013): 163-67. Stewart, Frances. Horizontal Inequalities and Conflict: Understanding Group Violence in Multiethnic Societies (Basingstoke, Palgrave MacMillan, 2016). 
UNOCI. "Civil Affairs." United Nations. https://onuci.unmissions.org/affaires-civiles-0 (accessed April 25, 2017).

UNOCI. confidential report.

World Bank. Project Information Document (PID), Appraisal Stage: Emergency PostConflict Assistance Project [en ligne], rapport $\mathrm{n}^{\circ} \quad$ AB3187, http://documents.banquemondiale.org/curated/fr/218321468770752305/Cote-dIvoireEmergency-Post-Conflict-Assistance-Project (accessed April 25, 2017). 